\title{
Clinical chemistry of farmed red deer (Cervus elaphus) yearling hinds reared on grass or papillonaceous pasture paddocks in Hungary
}

\author{
András Szabó1, János Nagy² , Julianna Bokor², Hedvig Fébel ${ }^{3}$, Róbert Romvári' , Dominika \\ Jónás ${ }^{1}$, Dávid Mezőszentgyörgyi ${ }^{4}$ and Péter Horn \\ ${ }^{1}$ Faculty of Agricultural and Environmental Sciences, Kaposvár University, Kaposvár, Hungary, ${ }^{2}$ Bőszénfa Deer Park, \\ Kaposvár University, Bőszénfa, Hungary, ${ }^{3}$ Research Institute for Animal Breeding, Nutrition and Meat Science, \\ National Agricultural Research Center, Herceghalom, Hungary, ${ }^{4}$ Education and Rural Development Institute, National \\ Agricultural Advisory, Budapest, Hungary
}

\begin{abstract}
Yearling red deer (Cervus elaphus) hinds of identical initial body weight were reared on a monocotyledonous grass (group 1) or on a papillonaceous plant pasture (group 2) for 212 days. At the end of the experiment (when deer were shot) blood was taken from ten animals of each group for serum biochemical analysis. Hinds of group 2 provided higher final body weight $(90 \pm 3.5$ vs. $101 \pm 6.6 \mathrm{~kg})$ and higher daily body weight gain $(105.7 \pm 10.7$ vs. $153.8 \pm 26.8 \mathrm{~g} /$ day). Within serum nitrogenous compounds group 2 provided higher total protein concentrations, while from the lipids only serum triglyceride levels were higher in this group. Serum potassium was in both groups higher than the reference range with a superposed slight hyperkalaemia in group 2. Higher lactate dehydrogenase and alkaline phosphatase activities were found in group 2 and lower aspartate aminotransferase activity values. Inorganic phosphate concentration showed a significant difference (group 1 provides higher values). Results refer to an expressed venison growth as a result of the rich dietary protein supply of group 2. Findings were evaluated as well with discriminant factor analysis, outlining the relative importance of the single blood biochemical parameters in shaping the inter-group differences.
\end{abstract}

Keywords: red deer, nutrition, grass, papillonaceae, clinical chemistry

Archiv Tierzucht 56 (2013) 43, 443-454

doi: 10.7482/0003-9438-56-043

Corresponding author:

András Szabó; email: szan1125@freemail.hu

Department of Food Development and Bioanalytics, Faculty of Agricultural and Environmental Sciences, Kaposvár University, 7400 Kaposvár, Guba S. u. 40., Hungary

() 2013 by the authors; licensee Leibniz Institute for Farm Animal Biology (FBN), Dummerstorf, Germany. This is an Open Access article distributed under the terms and conditions of the Creative Commons Attribution 3.0 License (http://creativecommons.org/licenses/by/3.0/).
Received: 21 November 2012

Accepted: 31 January 2013 Online: 27 March 2013 
Abbreviations: ADF: Acid Detergent Fibre; ADL: Acid Detergent Lignin; ALT: alanine aminotransferase; ALP: alkaline phosphatase; AST: aspartate aminotransferase; BW: body weight; CK: creatine kinase; DFA: discriminant factor analysis; GLM: general linear model; gamma-GT: gamma glutamyl transferase; HDL: high density lipoprotein; LDH: lactate dehydrogenase; LDL: low density lipoprotein; NDF: Neutral Detergent Fibre; TP: total protein; TG: triglyceride, VLDL: very low density lipoprotein

\section{Introduction}

Red deer (Cervus elaphus) is the most important big game of Hungary due to its large and imposing antler, unique rutting behaviour and newly its meat. Thus, farming or semicontrolled keeping is spreading in Hungary. In Cervidae, nutritional demands are mostly influenced by the ontogenetic growth and reproduction phase (e.g. rutting or lactation). Grazing on grasslands is a vital component of deer nutrition and according to Trdan \& Vidrih (2008), under moderate climate, herbage from grassland represents ca. $50 \%$ of the total diet during the spring-autumn period in wild living cohorts and food choice of Cervidae is rather conservative even under altered environmental conditions (Fischer et al. 2008). In Hungary, red deer are exposed to changing seasonal variations; the spring-summer phase diet consists of green plants and leaves of high nutritional value. To compensate for the winter and also the expressed mid-summer (a strong burden in Hungary) nutritionally challenging feed shortage, additional feeding (e.g. grass silage) is applied for semi-domestic populations. This is primarily reasoned by the fact that deer are not able to digest strongly fibrous components quickly or to store enough feed in their rumen compared to cattle (Short 1963).

To estimate the nutritional status and growth performance of Cervidae, blood sampling is the most widely used method (Reindeer and Svalbard Reindeer: Säkkinen et al. 2001, reindeer: Ropstad et al. 1997, Soppela et al. 2008, Iberian red deer (Cervus elaphus hispanicus): Gaspar-López et al. 2009, Rocky Mountain elk (Cervus elaphus nelsoni): Wolfe et al. 1982, red deer: Rosef et al. 2010, Soetrisno et al. 1994, Kent et al. 1980, Padilla et al. 2000). Säkkinen et al. (2001) proposed serum urea and creatinine and their quotient to estimate protein and energy intake. Deficient protein supply leads to decreased blood urea levels since deer recycle urea by low dietary protein intake (Hove \& Jacobsen 1975). In contrast, digestible protein load increases serum urea concentration, which may as well occur if low protein supply is coupled with energy restriction (Warren et al. 1982). According to Säkkinen et al. (2001), seasonalityassociated fasting and feed restriction increases serum creatinine levels in deer. This variation has been found to be related to changes of muscle mass and the excretion of creatinine (DelGiudice et al. 1992, Wolkers et al. 1994). Compared to pure perennial ryegrass (Lolium perenne), additive papillonaceous plants, such as red and white clover (Trifolium pratense and $T$. repens) provide augmented venison growth due to their higher protein, calcium and phosphorus contents (Soetrisno et al. 1994).

This study aimed to describe the metabolic reactions (via blood serum analysis) and growth of farmed red deer yearling hinds grazed on two, markedly different pastures of defined and known herbal and chemical composition in South-Western Hungary, Bőszénfa. 


\section{Material and methods}

Animals

The weaned red deer calves were penned in ten boxes for 20 individuals in each throughout the winter (from November to April) of 2010-2011. On the 11th of April 2011 (initial feed sampling and body weight measurement) 44 yearling hinds were allocated to two different pasture covered paddocks of each 2 ha ( 22 animals/paddock). Animals were only treated once during the entire study interval (June 2011) with Albendanin $5 \%$ suspension (Pharmatéka Inc., Budapest, Hungary), orally, as an anthelmintic treatment. The body weight (initial and final) of the deer is given in Table 1. On the 16th of November 2011 (final feed sampling and body weight measurement) deer were shot and hanged (onto a digital scale supported facility); the jugular vein was cut and effluent venous blood was collected. Blood samples of randomly selected ten hinds/group (total $n=2 \times 10=20$ ) were analysed. Tranquilisers were avoided since farmed deer venison served as a commercial product. The shooting was performed within ca. $10 \mathrm{~min}$. The study was performed under the hunting licence of the Bőszénfa Deer Park, allowance no.: 2/1364-2/2011 by the Somogy County Government Agency, Directorate of Agriculture.

Table 1

Body weight results of the deer in study

\begin{tabular}{lccc}
\hline Group & $1(\mathrm{n}=10)$ & $2(\mathrm{n}=10)$ & $P$ \\
Body weight, $\mathrm{kg}$ & Mean \pm SD & Mean \pm SD & $\mathrm{ns}$ \\
\hline Initial & $67.6 \pm 3.2$ & $68.4 \pm 4.4$ & $<0.0001$ \\
Final & $90.0 \pm 3.5$ & $101.0 \pm 6.6$ & $<0.0001$ \\
Body weight gain, g/day & $105.7 \pm 10.7$ & $153.8 \pm 26.8$ & \\
\hline
\end{tabular}

ns: $P>0.05$

\section{Feeding conditions}

The monocotyledonous grass based pasture (group 1) was dominantly composed of perennial ryegrass (Lolium perenne) and common meadow grass (Poa pratensis). The papillonaceous pasture (group 2) was based dominantly on alfalfa (Mecicago sativa ssp. varia), red clover (Trifolium pratense) and white clover (Trifolium repens). Pasture compositional sampling and analysis was performed with the Braun-Blanquet method (Podani 2006). In each paddock there were four measurements taken by the same diagonal way. Results of the plant composition are given in Table 3, while feed chemical composition is given in Table 2. Water was offered ad libitum. Additional feed ingredients (grain, etc.) were not fed at all.

\section{Blood serum analysis}

After withdrawal into Falcon $13 \mathrm{~mL}$ tubes the blood was immediately placed on ice, left to clot, centrifuged $(1500 \times \mathrm{g} / 10 \mathrm{~min})$ and serum was stored frozen $\left(-70^{\circ} \mathrm{C}\right)$ until analysis. Clinical chemical analysis was performed on automated equipment (Hitachi 917, Boehringer Mannheim, Germany) in a single analytical run. Reagent kits for triglyceride, total cholesterol, HDL and LDL cholesterol, albumin, total protein, creatine kinase, AST, ALT, urea and uric 
acid were purchased from Human Ltd. (Wiesbaden, Germany), reagents for creatinine and calcium were obtained from Roche Diagnostics (Quebec, Canada), those for phosphate and chloride from Pharmacia Biosystems (Freiburg, Germany), while those for gamma-GT, lipase, alkaline phosphatase and magnesium from Diagnosticum Ltd. (Budapest, Hungary). Na and $\mathrm{K}$ were measured with ion selective electrodes. Total lipid content was determined with the sulfophosphovanillin method, spectrophotometrically (Johnson et al. 1977).

Table 2

Feed chemical composition (initial and final samplings)

\begin{tabular}{lcccc}
\hline $\begin{array}{l}\text { pasture } \\
\text { group }\end{array}$ & Grass & Papillonaceae & Grass & $\begin{array}{c}\text { Papillonaceae } \\
2\end{array}$ \\
\hline Dry matter, \% & 1 & 2 & 1 & 21 \\
Crude protein, \%DM & 26.1 & 19.2 & 26.7 & 4.8 \\
Crude fat, \%DM & 2.2 & 3.7 & 3.3 & 0.4 \\
Crude fiber, \%DM & 0.5 & 0.4 & 0.6 & 3.2 \\
Crude ash, \%DM & 5.7 & 3.6 & 5.2 & 1.9 \\
N free extract, \%DM & 1.8 & 1.8 & 2.2 & 10.7 \\
NDF, \%DM & 15.9 & 9.7 & 15.7 & 6.2 \\
ADF, \%DM & 11.7 & 6.2 & 11.5 & 4.1 \\
ADL, \%DM & 7.4 & 4.4 & 5.9 & 0.7 \\
Hemicellulose, \%DM & 0.6 & 0.7 & 0.9 & 2.1 \\
Crude cellulose, \%DM & 4.3 & 1.8 & 5.6 & 3.4 \\
Ca, g/kg DM & 6.8 & 3.7 & 5 & 2.33 \\
P, g/kg DM & 1.93 & 2.8 & 1.18 & 0.73 \\
\hline
\end{tabular}

Table 3

Herbal composition of the paddocks

\begin{tabular}{lclr}
\hline Grass pasture & $\begin{array}{l}\text { Covered \% } \\
\text { of the area }\end{array}$ & Paillonaceous pasture & $\begin{array}{r}\text { Covered \% } \\
\text { of the area }\end{array}$ \\
\hline White clover (Trifolium repens) & & Alfalfa (Mecicago sativa ssp. varia) & $5.1-25$ \\
Red clover (Trifolium pratense) & $0.1-1$ & White clover (Trifolium repens) & $5.1-25$ \\
Perennial ryegrass (Lolium perenne) & $0.1-1$ & Red clover (Trifolium pratense) & $5.1-25$ \\
Soft brome (Bromus mollis) & $5.1-25$ & Perennial ryegrass (Lolium perenne) & $0.1-1$ \\
Common medow grass (Poa pratensis) & $1.1-5$ & Soft brome (Bromus mollis) & $0.1-1$ \\
Meadow fescue (Festuca pratensis) & $5.1-25$ & Common medow grass (Poa pratensis) & $0.1-1$ \\
Cock's foot (Dactylis glomerata) & $0.1-1$ & Meadow fescue (Festuca pratensis) & $0.1-1$ \\
Tall fescue (Festuca arundinacea) & $0.1-1$ & Field eryngo (Eryngium campestre) & $0.1-1$ \\
Eringeron annual (Stenactis annua) & $1.1-5$ & Common dandelion (Taraxacum officinale) & $0.1-1$ \\
Giant plumeless thistle (Carduus acanthoides) & $0.1-1$ & Broad-leaved Dock (Rumex obtusifolius L.) & $0.1-1$ \\
Field bindweed (Convolvulus arvensis L.) & $0.1-1$ & Common yarrow (Achillea millefolium) & $0.1-1$ \\
\hline
\end{tabular}

Italic typed plants are characteristic for only one pasture.

\section{Feed chemical composition analysis}

The chemical composition of the plant samples was determined according to the following methods: Dry matter: AOAC 934.01, vacuum oven; Crude Protein: Kjeldahl, AOAC 984.13; Ether extract: AOAC 920.39; Crude fibre: AOAC 978.10; Ash: AOAC 942.05; Nitrogen-free Extract 
calculation: 100 - (Moisture + Ash + Protein + C. fibre + Ether e.); Neutral Detergent Fibre (NDF): Holst (1973); Acid Detergent Fibre (ADF): AOAC 973.18; Acid Detergent Lignin (ADL): AOAC 973.18; Hemicellulose calculation: NDF-ADF. Ca and P were determined with flame atomic absorption spectroscopy, according to the AOAC methods $975.03 \mathrm{~B}$ and 966.01 , respectively.

\section{Statistics}

Initial and final body weight data, as well as body weight gain were compared with paired samples t-test, since deer were individually marked by ear tags. Blood serum parameters of the two groups were compared with analysis of variance (GLM procedure). The group was a fixed factor, while body weight was a covariant in the model. Factor effects are provided in Table 4.

Discriminant factor analysis (DFA) was performed on the dataset in order to identify the different groups based on the blood biochemical data. SPSS 10 for Windows (SPSS Inc., Chicago, IL, USA) and AlphaSoft 12.3 (Alpha M.O.S., Toulouse, France) were used for the analyses.

Table 4

Composition of the experimental groups

\begin{tabular}{|c|c|c|c|c|c|c|}
\hline Feeding & $\begin{array}{c}\text { Grass pasture } \\
\text { Mean } \pm S D\end{array}$ & $\begin{array}{c}\text { Papillonaceae } \\
\text { Mean } \pm \text { SD }\end{array}$ & $P$ & Group & BW & GXBW \\
\hline \multicolumn{7}{|l|}{ Nitrogenous compounds } \\
\hline total protein, $\mathrm{g} / \mathrm{L}$ & $65.9 \pm 4.38$ & $72.6 \pm 8.53$ & 0.016 & - & - & - \\
\hline albumin, $\mathrm{g} / \mathrm{L}$ & $24.7 \pm 3.56$ & $27.4 \pm 5.19$ & ns & - & - & - \\
\hline urea, $\mathrm{mmol} / \mathrm{L}$ & $7.46 \pm 0.89$ & $8.00 \pm 0.81$ & 0.092 & - & - & - \\
\hline uric acid, mmol/L & $1.90 \pm 0.99$ & $1.80 \pm 1.03$ & ns & - & - & - \\
\hline creatinine, $\mu \mathrm{mol} / \mathrm{L}$ & $103.9 \pm 22.8$ & $114.7 \pm 14.5$ & ns & - & - & - \\
\hline \multicolumn{7}{|l|}{ Lipid metabolites } \\
\hline total lipid, $\mathrm{g} / \mathrm{L}$ & $1.20 \pm 0.50$ & $1.55 \pm 0.70$ & ns & - & - & - \\
\hline triglyceride, $\mathrm{mmol} / \mathrm{L}$ & $0.13 \pm 0.04$ & $0.16 \pm 0.04$ & 0.006 & - & - & - \\
\hline total cholesterol, $\mathrm{mmol} / \mathrm{L}$ & $0.81 \pm 0.19$ & $0.98 \pm 0.37$ & ns & - & - & - \\
\hline $\mathrm{HDL}$ chol, $\mathrm{mmol} / \mathrm{L}$ & $0.53 \pm 0.12$ & $0.61 \pm 0.20$ & ns & - & - & - \\
\hline LDL chol, mmol/L & $0.22 \pm 0.08$ & $0.29 \pm 0.19$ & ns & - & - & - \\
\hline \multicolumn{7}{|l|}{ Ions } \\
\hline $\mathrm{Na}, \mathrm{mmol} / \mathrm{L}$ & $138.4 \pm 7.02$ & $140.2 \pm 2.11$ & ns & - & - & - \\
\hline $\mathrm{K}, \mathrm{mmol} / \mathrm{L}$ & $4.95 \pm 0.48$ & $5.64 \pm 0.77$ & 0.046 & - & - & 0.092 \\
\hline $\mathrm{Ca}$, total, $\mathrm{mmol} / \mathrm{L}$ & $2.17 \pm 0.25$ & $2.35 \pm 0.23$ & ns & - & - & - \\
\hline $\mathrm{Ca}$, ion, $\mathrm{mmol} / \mathrm{L}$ & $1.34 \pm 0.17$ & $1.45 \pm 0.19$ & ns & - & - & - \\
\hline $\mathrm{P}$ inorg, $\mathrm{mmol} / \mathrm{L}$ & $2.11 \pm 0.33$ & $1.72 \pm 0.24$ & 0.007 & - & - & - \\
\hline $\mathrm{Cl}, \mathrm{mmol} / \mathrm{L}$ & $97.9 \pm 7.84$ & $100.2 \pm 6.29$ & ns & - & - & - \\
\hline $\mathrm{Mg}, \mathrm{mmol} / \mathrm{L}$ & $0.69 \pm 0.07$ & $0.73 \pm 0.07$ & ns & - & - & - \\
\hline \multicolumn{7}{|l|}{ Enzymes } \\
\hline LDH, IU/L & $843.9 \pm 246.6$ & $1003.5 \pm 290.0$ & 0.048 & - & - & - \\
\hline AST, IU/L & $111.1 \pm 110.5$ & $101.9 \pm 30.0$ & 0.029 & 0.084 & - & - \\
\hline$A L T, I U / L$ & $37.1 \pm 12.59$ & $43.4 \pm 12.6$ & ns & - & - & - \\
\hline gamma-GT, IU/L & $27.3 \pm 27.37$ & $15.7 \pm 4.27$ & ns & - & - & - \\
\hline lipase, IU/L & $42.3 \pm 12.93$ & $50.4 \pm 10.6$ & ns & 0.024 & 0.035 & 0.036 \\
\hline alkaline phosphatase, IU/L & $113.9 \pm 50.85$ & $168.3 \pm 64.0$ & 0.048 & 0.076 & - & - \\
\hline creatine kinase, IU/L & $526.0 \pm 121.3$ & $757.6 \pm 321.1$ & ns & - & - & - \\
\hline
\end{tabular}

ns: $P>0.05$; Inter-group comparison and the effect of group, body weight and their interaction on the differences; Bold lines indicate significant difference between groups on different pasture types. 


\section{Results}

\section{Growth}

The final body weight (BW) of group 2 reached significantly higher values and the daily BW gain provided a similar difference (Table 1).

\section{Blood serum}

Nitrogenous compounds

The serum total protein (TP) level was higher in group 2 reared on papillonaceous plants (Table 4). In contrast, albumin, uric acid and creatinine did not differ in the two groups, meanwhile serum urea concentration was slightly, but not significantly higher in group 2 .

\section{Lipid metabolites}

While total lipid, total, HDL and LDL cholesterol tended to be higher in group 2, statistical significance was only proven for triglyceride concentration; higher values were measured in group 2.

\section{Serum ions}

No inter-group differences were found between serum sodium, total and ionic calcium, chloride and magnesium concentrations. In contrast, higher potassium concentration was found in group 2 (with significant group $\times B W$ interaction). Group 1 reared on monocotyledonous grass pasture provided higher inorganic phosphate concentrations in the sera.

\section{Enzymes}

Lactate dehydrogenase (LDH) and alkaline phosphatase (ALP) activities were significantly higher in group 2 (compared to group 1), while aspartate aminotransferase (AST) activity was lower in this group. Alkaline phosphatase was significantly influenced by group, as a fixed factor, while for AST a similar, borderline significant effect was proven. Alanine aminotransferase (ALT), gamma-GT, lipase and creatine kinase (CK) activities were not different between groups.

\section{Discriminant factor analysis}

In the discriminant factor analysis factor 1 (parallel with the horizontal axis) was covering practically $100 \%$ of the variance, resulting to a robust (100\%) differentiation of the two groups. The biochemical factors playing the most determinant role in the discrimination were those characterised by the most horizontal and long vectors in Figure 1. 


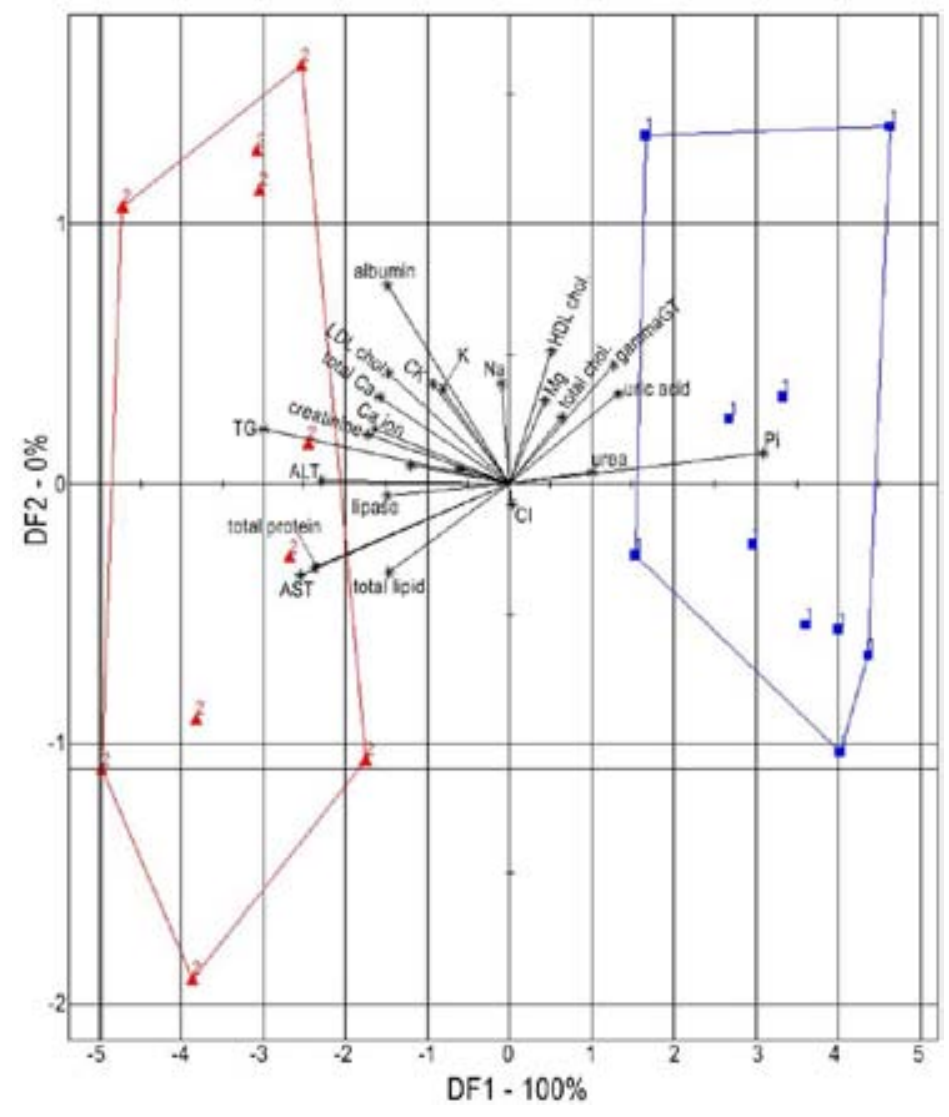

Figure 1

The effects of the two discriminating functions on the separation of the deer groups (horizontal: DF1; vertical: DF2)

\section{Discussion}

\section{Blood serum}

\section{Nitrogenous compounds}

Nutritional status is primarily evaluated in deer taking serum nitrogenous compounds into consideration (DelGuidice et al. 1992, 1994, Phillip et al. 2007). This is based on the condition that deer are able to conserve nitrogen when protein restriction occurs via increased renal re-absorption and urea recycling, thus limiting urinary nitrogen loss (Robbins et al. 1974). According to Thrall (2004), serum total protein (TP) concentration increases with aging in deer and reachs a plateau at about ten months of age. The hinds of this study were allocated to the different pasture types at the age of 11 months, thus, serum TP differences were attributed to the diet-compositional differences. The TP concentrations of both groups fall into the reference range of red deer $(54-81 \mathrm{~g} / \mathrm{l})$, as reported by Kent et al. (1980). Rosef et al. (2010) reported on a lower TP interval (63.6-66.3 g/l) for free living deer in Norway, while high altitude $(2450 \mathrm{~m}$ ) keeping (Mexico) led to higher values (50-80 g/l, Padilla et al. 2000). Based on the above-mentioned results it was stated that elevated dietary protein content 
can significantly increase serum protein concentration of farmed red deer hinds. This was further supported by the results of Soppela et al. (2008) in reindeer undergoing a lichenreindeer pellet feed transition coupled with increasing total serum protein levels. Moreover, Figure 1 accurately demonstrates the role of total serum protein in the discrimination of the groups, the vector is directly pointing to group 2.

The main role of albumin is maintaining the oncotic pressure in the vascular system, thus its concentration is less variable, as it was found in our study as well. In contrast, we found lower albumin values than Rosef et al. (2010, 35.7-37.5 g/l in red deer) and English \& Lepherd (1981, 30.3-35.3 $\mathrm{g} / \mathrm{l}$ in fallow deer) in all instances in free living cohorts.

For body condition estimations creatinine concentration (mostly as an urinary excrete) is favoured in deer. This is underpinned by several factors: creatinine is excreted at a rather constant diurnal rate, after complete glomerular filtration and minimal re-absorption in mammals. According to DelGiudice et al. (1994), urinary creatinine concentration is not affected by herbivorous diets, but is a correlate of mass-specific nitrogen intake and is thus related to lean muscle mass. While our data failed to provide a significant relation of serum creatinine to body weight, total serum protein content was significantly related with it (Pearson correlation coefficient $r=0.625, P=0.007$ ). According to Soppela et al. (2008), increased serum creatinine levels (over $250 \mu \mathrm{mol} / \mathrm{l}$ ) are associated with tissue protein catabolism induced by dietary protein shortage. We report the opposite, low serum creatinine levels are associated with optimal dietary protein supply and higher muscle mass. (For uric acid a similar tendency was found as for urea (and creatinine), but without significant inter-group differences.)

In ruminants dietary protein intake, but rather rumen degradable protein intake is reflected by serum urea concentration, but is as well related to its balance to fermentable metabolic energy. According to our results, feed compositional differences (crude protein) were only slightly (but not significantly) reflected by the serum urea concentration. This lack of difference, even with largely different (nearly 2-fold) crude protein intake and serum levels is interesting, because the papillonaceous mixture was rather rich in crude protein compared to grass pasture. The rumen degradability of the protein in the two feed sources is rather similar, as reported by Cassida et al. (2000). However, the marked difference in the dietary level of NDF and ADF, on the excess of the grass mixture (group 1), results in a higher structural fibre content, leading to a slower rumen outflow rate of this feed source. The longer rumen degradation may lead ultimately to lower feed intake, which is disadvantageous for the microflora. In contrast, the rumen fermentation of the papillonaceous feed, due to its lower structural fibre (NDF and ADF) content, is quick, ensuring a higher substrate concentration for the microbiota per time unit, leading to a more intensive rate of ruminal fermentation. Thus, microbial ammonia utilisation and protein synthesis is augmented by the higher energy supply. The intensive microbial protein synthesis leads finally to a higher microbially synthesised protein content in the small intestine, resulting in an elevated amino acid absorption and a better protein supply of the animals of the latter group (2). The more efficient microbial ammonia utilisation was indicated by the fact that higher protein intake from the papillonaceous pasture did not ultimately lead to an elevation of the serum urea level in group 2. This is moreover also supported by the fact that not only blood TP, but also the body weight gain of group 2 was significantly higher. 


\section{Enzymes}

According to Thrall (2004), deer are anxious animals; hence any handling related excitement leads to increased serum CK, LDH and AST activities. In our study the hunting of animals was performed very quickly, thus, the burden of premortal stress in this context can be excluded from the etiological factors. We rather suppose an expressed muscular growth in group 2, as a partial result of the ad libitum feeding with a high-protein diet. The diet composition of group 2 was uncommon, namely free-living deer are rarely supplied with high-protein sources (Mitchell et al. 1977). (The slight hyperkalaemic status (compared to group 1) of these animals seems to support higher muscle mass as well; see ions section) Moreover, AST was lower in group 2 providing higher LDH (and slightly higher CK) activities, contradicting to marked premortal stress.

In our case deer were $a b$ ovo providing relatively high CK enzyme activity values, e.g. compared to data of Kent et al. (1980; 12-250 IU/I in shot deer) and Rosef et al. (2010; $266 \pm 253 \mathrm{IU} / \mathrm{I}$ in tranquillised free ranging deer) most probably associated with expressed muscle growth (Thrall 2004) and their farmed, fenced keeping conditions. The CK activity values in this cohort (both groups) were higher compared to free-living (Padilla et al. 2000; $221 \pm 103 \mathrm{IU} / \mathrm{l})$, restrained sampled animals and also higher than in New Zealand farmed deer (Wilson \& Pauli 1983, 197.9IU/I). Samplings in both cited cases were performed without tranquilisation.

Alkaline phosphatase is a membrane-bound enzyme and its activity is expressed in osteoblasts, biliary and renal epithelium and intestines (Thrall 2004). This analysis handled the isoforms not separately, but compared to relevant literature (Kent et al. 1980; 3-36 IU/I, Rosef et al. 2010; 224 \pm 130 IU/I) we found either lower or consonant results. Animals involved were yearling hinds, thus, antler ossification effects were excluded. The Ca supply was nearly two-fold higher in the papillonaceous pasture, while an opposite, but less expressed trend was found for dietary phosphorus ( $\mathrm{Ca} / \mathrm{P}$ ratios of 1.39 and 3.19 in the papillonaceous and the grass pastures, resp.). In addition, sexual activity was already ceased, as assessed by the absence of visible corpus luteum in the hinds. While significant correlation was found neither between carcass bone content nor serum Pi levels, serum Ca concentration provided a significant correlation with ALP ( $r=0.48, P=0.008)$. Moreover, dietary protein supply has as well been published to increase serum ALP activities (Klinger et al. 1986, white tailed deer), and the relationship is met primarily via the augmented growth (Table 1) and the coupled ossification needs of young and growing hinds. In addition, this was as well fortified with the rich dietary Ca supply compared to the grass pasture reared deer.

\section{Ions}

From the two most abundant ions $\mathrm{Na}$ and $\mathrm{Cl}$ were not significantly different between groups. Serum sodium level is regulated by glomerular filtration, re-absorption or renal excretion. The extent of sodium and chloride re-absorption is shaped by physiological needs. In this study both ion concentrations definitely fluctuated around literature data for red deer (Padilla et al. 2000, Rosef et al. 2010). In Figure 1, discriminant factor 1 had a separation efficiency of $100 \%$, thus, horizontal vector-like biochemical factors contributed largely to the spatial separation of the groups. It is clearly visible that $\mathrm{Na}$ aligns to a vertical vector with minimal length (such as $\mathrm{Cl}$ ), referring to its nearly constant concentration in a group-independent manner. 
In contrast $\mathrm{K}$ did differ between groups, on the excess of the larger bodied deer (group 2). The serum potassium concentration of deer was not pathologic, as Rosef et al. 2010 provided a reference range of $5.5-6.6 \mathrm{mmol} / \mathrm{l}$, while the International Species Information System (ISIS 2002) applies a range for K in Cervidae of $4.3 \pm 0.9 \mathrm{mmol} / \mathrm{l}$. Interestingly, Stringer et al. (2011) reported on hyperkalaemia in free-ranging white-tailed deer with unknown etiology, excluding late serum separation, dietary factors, poor nitrogen supply and premortal stress. Interestingly, CK, LDH and K were not providing a significant correlation in our study with the $K$ concentration values. Thus, mild hyperkalaemia was rather attributed to slight osmotic changes.

In contrast, inorganic $\mathrm{P}$ provided an opposite inter-group difference as also indicated in Figure 1. The reason of the difference not agreeing with the dietary levels may be that ALP activity and somatic growth, and thus Pi demand of group 2 was more expressed, sequestering the substrate from the blood circulation. Neither total, nor ionic Ca was different between groups in spite the large dietary difference, most probably due to hormonal control. Magnesium concentrations of the sera in both groups were similar to those in the relevant studies (Padilla et al. 2010, 0.91 \pm 0.2 , Rosef et al. 2010, 0.48 $\pm 0.11 \mathrm{mmol} / \mathrm{l}$ ).

\section{Lipid metabolites}

Dietary crude fat content was less different between the two diets (Table 1). Although nearly all lipoprotein fractions analysed (total, HDL and LDL cholesterol) tended to be higher in group 2 , only triglyceride (TG) concentrations were statistically higher in this group. Circulating TG concentrations resemble the balance between hepatic synthesis and secretion and adipose tissue uptake (Dijkstra et al. 2005). Thus, higher serum TG levels refer to an augmented hepatic secretion via VLDL, most probably related to rich energy supply. This was accompanied by a slightly (but not significantly) elevated pancreatic lipase activity. Comparing our results to captive (Peinado et al. 1999, 0.07-0.09 mmol/l) or free ranging deer (Rosef et al. 2010: $0.1 \pm 0.08 \mathrm{mmol} / \mathrm{l}$ ), we found higher levels in both groups. Lipoprotein synthesis of Cervidae is a less studied area, but similarly to other ungulates, circulating TG is mostly present in the form of chylomicrons of intestinal and VLDL of intestinal and hepatic origin. Compared to domestic ruminant feeds, the feed of deer in this study was a low-fat diet. Thus, we supposed behind the results the relative rich energy supply compared to wild foraging circumstances.

Based on our results the conclusions can be drawn that in red deer yearling hinds, reared either on a monocotyledonous grass mixture (1) or on a pure papillonaceous plant pasture (2) under farmed conditions for 212 days, the higher dietary protein content led to markedly higher body weight gain and higher serum total protein levels. Results refer to the need of digestibility studies on red deer unexplored from this aspect. The protein rich papillonaceous diet let to a higher muscle mass, leading ultimately to slightly, but not pathologically elevated potassium and AST levels, while ossification needs were met by elevated ALP activities. Lipid metabolites showed minor inter-group differences.

\section{Acknowledgements}

The study was supported by the Bolyai János Research Grant by the Hungarian Academy of Sciences (BO_26/11/4 to A.Sz.) and by the TÁMOP 422A-KONV-2012-0039 project. 


\section{References}

AOAC (2006) Official methods of analysis of AOAC International. Gaithersburg, MD, USA

Cassida KA, Griffin TS, Rodriguez J, Patching SC, Hesterman OB, Rust SR (2000) Protein Degradability and Forage Quality in Maturing Alfalfa, Red Clover, and Birdsfoot Trefoil. Crop Sci 40, 209-215

DelGiudice GD, Mech LD, Kunkel KE, Gese EM, Seal US (1992) Seasonal patterns of weight, hematology, and serum characteristics of free-ranging female white-tailed deer in Minnesota. Can J Zool 70, 974-983

DelGiudice GD, Mech LD, Seal US (1994) Undernutrition and Serum and Urinary Nitrogen of White-Tailed Deer during Winter. J Wildl Manage 58, 430-436

Dijkstra J, Forbes JM, France J (eds.) (2005) Quantitative aspects of ruminant digestion and metabolism. 2. ed. CABI Publ., Wallingford, UK

English AW, Lepherd EE (1981) The haematology and serum biochemistry of wild fallow deer (Dama dama) in New South Wales. J Wildl Dis 17, 289-295

Fischer A, Schalitz G, Behrendt A (2008) Comparative studies on the grazing behaviour of fallow deer and sheep in winter. Arch Tierz 51, 487-497

Gaspar-López E, Casabiell J, Estevez JA, Landete-Castillejos T, de La Cruz LF, Gallego L, García AJ (2009) Seasonal changes in plasma leptin concentration related to antler cycle in Iberian red deer stags. J Comp Physiol B 179, 617-622

Holst DO (1973) Filtration apparatus for Van Soest detergent fiber analysis. J Assoc Off Anal Chem 56, 1352-1356

Hove K, Jacobsen E (1975) Renal excretion of urea in reindeer: Effect of nutrition. Acta Vet Scand 16, 513-519

ISIS (2002) Physiologic data reference values. ISIS Apple Valley, MN, USA

Johnson KR, Ellis G, Toothill C (1977) The Sulfophosphovanillin Reaction for Serum Lipids: A Reappraisal. Clin Chem 23, 1669-1678

Kent JE, Chapman DI, Chapman NG (1980) Serum constituents of red deer. Res Vet Sci 28, 55-57

Klinger SR, Robel RJ, Brown BA, Brent BE (1986) Blood characteristics of white-tailed deer from northeastern Kansas. J Wildl Dis 22, 385-388

Mitchell B, Staines BW, Welch D (1977) Ecology of Red Deer. A research review relevant to their management in Scotland. Institute of Terrestrial Ecology, National Environment Research Council, Cambridge, UK

Padilla S, Bouda J, Quiroz-Rocha GF, Dávalos JL, Sánchez A (2000) Biochemical and Haematological Values in Venous Blood of Captive Red Deer (Cervus elaphus) atHhigh Altitude. Acta Vet Brno 69, 327-331

Podani J (2006) Braun-Blanquet's legacy and data analysis in vegetation science. J Veget Sci 17, 113-117

Peinado VI, Celdrán JF, Palomeque J (1999) Blood biochemistry values in some wild ruminants in captivity. Comp Haematol Int 9, 175-181

Phillip LE, Oresanya TF, Jacques JS (2007) Fatty acid profile, carcass traits and growth rate of red deer fed diets varying in the ratio of concentrate: dried and pelleted roughage, and raised for venison production. Small Rumin Res 71, 215-221

Robbins CT, Prior RL, Moen AN, Visek WJ (1974) Nitrogen Metabolism of White-Tailed Deer. J Anim Sci 38, 186-191

Ropstad E, Johansen O, Halse K, Morberg H, Dahl E (1997) Plasma magnesium, calcium and inorganic phosphorus in Norwegian semi-domestic female reindeer (Rangifer tarandus tarandus) on winter pastures. Acta Vet Scand 38, 299-313

Rosef O, Nystøyl HL, Solenes T, Arnemo JM (2010) Haematological and serum biochemical reference values in free-ranging red deer (Cervus elaphus atlanticus). Rangifer 24, 79-85

Säkkinen H, Stien A, Holand O, Hove K, Eloranta E, Saarela S, Ropstad E (2001) Plasma Urea, Creatinine, and Urea: Creatinine Ratio in Reindeer (Rangifer tarandus tarandus) and in Svalbard Reindeer (Rangifer tarandus platyrhynchus) during Defined Feeding Conditions and in the Field. Physiol Biochem Zool 74, 907-916

Short HL (1963) Rumen Fermentations and Energy Relationships in White-Tailed Deer. J Wildl Manage 27, 184-195 
Soetrisno E, Barry TN, Wilson PR, Hodgson J, Purchas RW (1994) Effects of grazing red clover (Trifolium pratense) or perennial ryegrass (Lolium perenne)/white clover (Trifolium repens) pastures upon growth and venison production from weaner red deer (Cervus elaphus). N Z J Agr Res 37, 19-27

Soppela P, Saarela S, Heiskari U, Nieminen M (2008) The effects of wintertime undernutrition on plasma leptin and insulin levels in an arctic ruminant, the reindeer. Comp Biochem Physiol B 149, 613-621

Stringer EM, Kennedy-Stoskopf S, Chitwood MC, Thompson JR, DePerno CS (2011) Hyperkalemia in freeranging white-tailed deer (Odocoileus virginianus). J WildI Dis 47, 307-413

Thrall MA (ed.) (2004) Veterinary Hematology and Clinical Chemistry. Lippincott Williams \& Wilkins, Philadelphia, PA, USA

Trdan S, Vidrih M (2008) Quantifying the damage of red deer (Cervus elaphus) grazing on grassland production in southeastern Slovenia. Eur J Wildl Res 54, 138-141

Warren RJ, Kirkpatrick RL, Oelschlaeger A, Scanlon PF, Webb KR Jr., Whelan JB (1982) Energy, Protein and Seasonal Influences on White-Tailed Deer Fawn Nutritional Indices. J Wildl Manage 46, 302-312

Wilson PR, Pauli JV (1983) Blood constituents of farmed red deer (Cervus elaphus). II: biochemical values. N Z Vet J 31, 1-3

Wolfe G, Kocan AA, Thedford TR, Barron SJ (1982) Hematologic and serum chemical values of adult female Rocky Mountain elk from New Mexico and Oklahoma. J Wildl Dis 18, 223-227

Wolkers H, Wensing T, Schonewille JT (1994) Effect of undernutrition on haematological and serum biochemical characteristics in red deer (Cervus elaphus). Can J Zool 72, 1291-1296 